Policy Research Working Paper 2216

Corruption and Trade

Tariffs, or a Case for

A highly diversified trade tariff

menu may fuel bribe-taking

behavior. Setting trade tariff

Uniform Tariffs

rates at a uniform level limits

public officials' ability to

extract bribes from importers.

Roberta Gatti

The World Bank

Development Research Group

Macroeconomics and Growth

November 1999 
POlicy Research WORKIng PAPER 2216

\section{Summary findings}

By explicitly accounting for the interaction between importers and corrupt customs officials, Gatti argues that setting trade tariff rates at a uniform level limits public officials' ability to extract bribes from importers.

If the government's main objective is to raise revenues at the minimum cost to welfare, optimally-set tariff rates will be inversely proportional to the elasticity of demand for imports. So they will generally differ across goods.

Such a menu of tariff rates endows customs officials with the opportunity to extract rent from importers. If officials have enough discretionary power, they might threaten to misclassify goods into more heavily taxed categories unless importers pay them a bribe. Because of the bribe, the effective tariff rate for the importing firm increases, so demand for the good decreases.

The resulting drop in import demand implies an efficiency loss as well as lower government revenues, compared with the optimal taxation benchmark without corruption.

A similar argument applies when customs officials offer to classify goods into low-tariff categories in exchange for a bribe.

Setting trade tariffs at a uniform level eliminates officials' opportunities to extract rents. Thus, when corruption is pervasive, a uniform tariff can deliver more government revenues and welfare than the optimally set (Ramsey) tariff benchmark.

The empirical evidence confirms that these considerations are relevant to policymaking, since a robust association between the standard deviation of trade tariffs - a measure of the diversification of tariff menus - and corruption emerges across countries.

This paper - a product of Macroeconomics and Growth, Development Research Group - is part of a larger effort in the group to study corruption. Copies of the paper are available free from the World Bank, $1818 \mathrm{H}$ Street NW, Washington, DC 20433. Please contact Roberta Gatti, room MC3-353, telephone 202-473-8735, fax 202-522-3518, Internet address rgatti@worldbank.org. Policy Research Working Papers are also posted on the Web at http://wbln0018.worldbank.org/ research/workpapers.nsf/policyresearch?openform. October 1999. (16 pages)

The Policy Research Working Paper Series disseminates the findings of work in progress to encourage the exchange of ideas about development issues. An objective of the series is to get the findings out quickly, even if the presentations are less than fully polished. The papers carry the names of the authors and should be cited accordingly. The findings, interpretations, and conclusions expressed in this paper are entirely those of the authors. They do not necessarily represent the view of the World Bank, its Executive Directors, or the countries they represent. 


\title{
Corruption and Trade Tariffs, or a Case for Uniform Tariffs
}

\author{
Roberta Gatti ${ }^{1}$ \\ The World Bank \\ Development Research Group
}

\footnotetext{
${ }^{1}$ I thank Ulrich Hess, William Easterly, Aart Kraay, Michael Kramer, Maria Soledad Martinez Peria and, in particular, Marcelo Olarreaga and James Roaf for useful comments and discussions. Please address correspondence to rgatti@worldbank.org.
} 



\section{Introduction}

"If I am born again, I want to come back as a custom official."

Anonymous Thai businessman ${ }^{2}$

The issue of a uniform tariff across goods has received substantial attention by both economists and policymakers. Among other things, uniform tariffs have been shown to reduce gains from lobbying for protection and thus enhance economic efficiency, increase the cost to future governments of protecting favored sectors, and in general improve transparency. Notwithstanding its appeal and simplicity, only few countries Bolivia, Chile, and to some extent Mexico - have so far opted for a uniform trade tax structure. $^{3}$

Besides likely political obstacles to its implementation, the case for uniform tariffs appears to be weakened if the government's main objective is raising revenues. From optimal taxation theory we know that revenues can be raised at the minimum efficiency cost by taxing at higher rates goods with less elastic demand schedules. Optimally set tariff rates would therefore generally differ across goods.

In this work, we show how explicitly accounting for possible interactions between importers and customs officials might alter the normative prescription of optimal taxation theory. In particular, we show that, if the government's objective is to raise revenue at the minimum cost in terms of efficiency, and customs officials are corrupt, a uniform tariff may be preferable to differentiated tariffs, because it may yield the government higher revenues as well as improve welfare.

Whenever tariffs differ across goods, the wedge between them gives customs officials room to extract rents from importers. Corrupt officials might threaten to misclassify imports into more heavily taxed categories unless the importers agree to pay them a bribe. Alternatively, the officials might offer to misclassify goods into less heavily taxed categories in exchange for bribes. We will see that this interaction gives rise to resource transfers among the players and to government revenue losses. Moreover, whenever the

\footnotetext{
2 I thank David Dollar for this illuminating quote.

${ }^{3}$ See Panagariya and Rodrick (1993) for an in-depth discussion of these issues.
} 
bribe increases the effective price paid by importers, import quantity decreases and so does welfare. Finally, the likely bargaining between officials and importers to reach an agreement can be time-consuming and wasteful in itself.

The flexibility of taxing goods at different rates comes therefore at a cost in terms of efficiency, revenues, and time, if officials are corrupt. By restricting the ability of customs officials to appropriate government revenues and to impose unnecessary efficiency losses on the economy, a uniform tariff structure can instead deliver higher revenues and welfare.

Empirical evidence confirms that the diversification of trade tariffs across goods might actually fuel corruption, in that a measure of such diversification - the standard deviation of trade tariffs across goods - appears to be robustly associated with reported corruption across countries.

This argument is relevant to policy in many countries. A standard recommendation to developing countries is to shift away from protectionist regimes in order to obtain efficiency gains (see for example Thomas and Nash 1991). Often these countries are reluctant to decrease tariff barriers because of the implied fiscal revenue loss. To the extent that customs administrations are plagued by corruption and customs officials appropriate government revenues in the way we described, shifting trade tariffs towards a uniform low level could allow countries to obtain efficiency gains without incurring major revenue losses.

The paper is structured as follows. Section two develops a simple graphical argument illustrating the main points. Section three presents the empirical test. Section four concludes.

\section{Optimal Trade Tariffs à la Ramsey and Corruption}

Consider a small open economy where importers are price takers and trade tariffs are set to maximize welfare subject to the constraint that the government raises some revenue $R$. This is a standard optimal taxation type problem, first formulated by Frank Ramsey. In a two-good world, the government will choose tariffs $t_{l}$ and $t_{2}$ to maximize the indirect utility from good $l$ and good $2, v(\cdot)$, subject to the constraint of raising revenue $R$ 


$$
\begin{gathered}
\max _{t_{1}, t_{2}} v\left(p_{1}+t_{1}, p_{2}+t_{2} ; m\right) \\
\text { s.t. } t_{1} x_{1}\left(p_{1}+t_{1}, m\right)+t_{2} x_{2}\left(p_{2}+t_{2}, m\right) \geq R
\end{gathered}
$$

where $p_{i}$ and $t_{i}$ are respectively price and tariff rate of good $i, m$ is income, and $x_{i}$ is the import demand for good $i$.

The solution to this problem implies that tariffs on each good will be set to be inversely proportional to the price elasticity of demand $\left(\varepsilon_{i}\right) .{ }^{4}$ Therefore, $t_{1}^{o}=\frac{k}{\varepsilon_{1}}$ and $t_{2}^{o}=\frac{k}{\varepsilon_{2}}$, where $k$ is a constant and the superscript $o$ stands for optimally set tariffs. If $\varepsilon_{1}>$ $\varepsilon_{2}$, then $t_{1}^{\circ}<t_{2}^{o}$.

Let us also label $x_{1}^{\circ}$ and $x_{2}^{\circ}$ the levels of import chosen by firm $I$ and firm 2 when market prices for good 1 and good 2 are $p_{1}$ and $p_{2}$ and tariffs are set as above.

Suppose now that good $l$ and good 2 are sufficiently similar that their classification as "good 1 " and "good 2" is not crystal clear. Dishonest customs officials might then try to exploit the wedge between the tariff rates by (a) threatening to classify good $l$ as the more heavily taxed good 2 unless paid a bribe or (b) offering to classify good 2 as the less heavily taxed good $I$ in exchange for a bribe. ${ }^{5}$ In other words, the Ramsey tariff structure endows corrupt customs officials with a form of rent.

Figure 1 illustrates the impact of interactions (a) and (b) - which we label "threat" and "lure" respectively - between customs officials and importers. In the picture, $x_{l}\left(p_{l}\right)$ and $x_{2}\left(p_{2}\right)$ are demand schedules for import goods $I$ and 2 , with price elasticities $\varepsilon_{1}>\varepsilon_{2}$. Because of this, we saw that optimally set tariffs are such that $t_{1}^{o}<t_{2}^{o}$.

In both scenarios, bargaining is likely to take place and the bribe will tend to be smaller than the full difference between the tariff rates $t_{2}^{o}$ and $t_{1}^{\circ}$. However, for simplicity, we abstract for now from the dynamics of the bargaining process and assume that the official is able to twist it to her complete favor and can therefore appropriate the entire rent.

\footnotetext{
${ }_{5}^{4}$ See Varian (1992) for a standard proof of the argument.

${ }^{5}$ In this work, we restrict the attention to misclassification of import categories and assume away the possibility that customs officials collude with importers to smuggle import quantities.
} 
The effects of corruption are easily seen in the "threat" case. Because of the bribe, the effective price paid by firm 1 for its good increases. This in turn drives down demand so that only $\hat{x}_{1}<x_{1}^{\circ}$ is imported. As a result of the shrinking tax base, the government loses $\left(x_{1}^{o}-\hat{x}_{1}\right) t_{1}^{o}$ in revenues. The official appropriates $\left(t_{2}^{o}-t_{1}^{o}\right) \hat{x}_{1}$ of the importers' surplus. Finally, $1 / 2\left(t_{2}^{o}-t_{1}^{o}\right)\left(x_{1}^{o}-\hat{x}_{1}\right)-$ represented in Figure 1 by the triangle CDE - is lost in firm surplus altogether. When compared to the no-tariff situation, the overall efficiency loss implied by the imposition of tariff $t_{1}^{o}$ augmented by the bribe amounts to the triangle $\mathrm{AFE}$ and is analogous to the effect of setting the tariff on good $l$ to $t_{2}^{\circ}$.

In the "lure" scenario, under the assumption that the official pockets the full rent, the effect of corruption is a straightforward transfer of revenues from the government to customs officials. The final price of the good, and thus the imported quantity $x_{2}^{\circ}$, stay unchanged and no efficiency loss ensues.

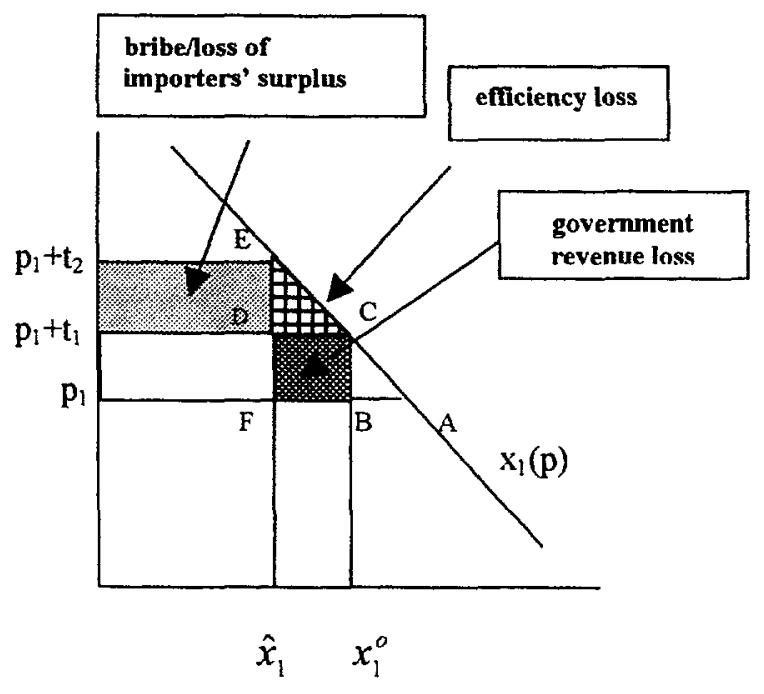

(a) The "threat" case

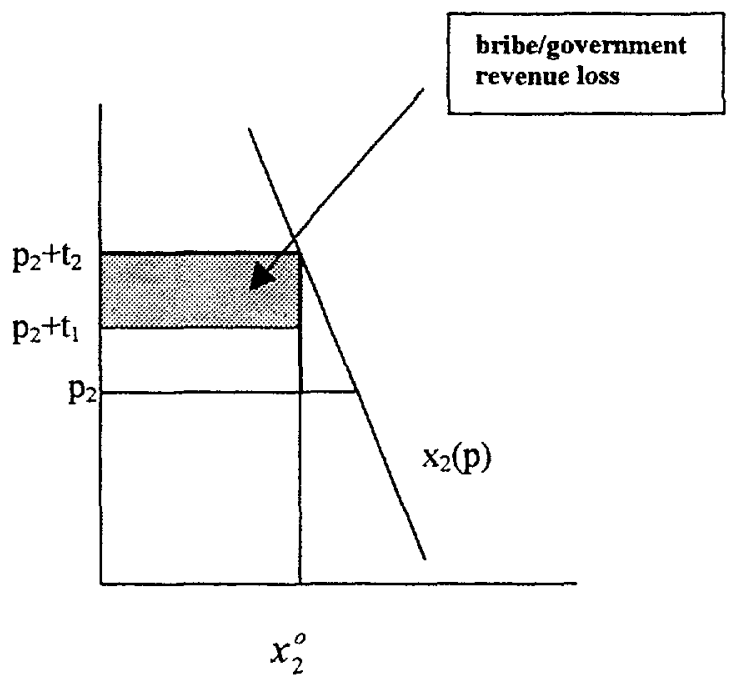

(b) The "lure" case

Figure 1

The impact of corruption is now apparent: an efficiency loss accompanied by a revenue loss (in the "threat" case) and a transfer of resources from the firm (in the "threat" case) and from the government (in the "lure" case) to the officials. To the extent that the government must raise other, possibly more distortionary, taxes to recover the 
revenue loss, the resource transfer away from the government can imply a further efficiency loss per se.

It is easy now to see how a different balance of power in the bargaining between importers and customs officials might modify the payoffs for the three agents in play. In the "threat" case, if importers and officials split returns 50-50, the effective tariff faced by

the importer is $t^{50-50}=1 / 2\left(t_{1}^{o}+t_{2}^{o}\right)$. Expected imported quantity of good $1, x_{1}^{50-50}$, will be lower than the quantity associated with the optimal tariff $t_{1}^{o}$ without corruption, but higher than the quantity prevailing if the official were to pocket the whole surplus. This implies, in turn, that the government loses relatively less revenues and also that less is lost in welfare, compared to the case where the full rent accrues to the official.

If payoffs are split 50-50 in the "lure" case, the firm faces a reduced effective tariff rate. This drives up imported quantity of good 2 and, because of this, both welfare and government revenues increase relative to the case where the full rent accrues to the official.

The comparison of the "threat" and "lure" interactions under the 50-50 bargaining rule with the Ramsey benchmark without corruption is likely to produce less startling differences than the case where officials pocket the full rent. Nonetheless, the spirit of the results - that these interactions imply government revenue and possibly welfare losses stays unchanged.

We carried out this analysis under the implicit assumption that the government does not monitor custom officials. Reversing this assumption would not substantially change the analysis but would introduce complications. Monitoring is likely to decrease the ability of officials to appropriate government resources - or force them to share the spoils with the monitors - and to impose the distortions we described. Nonetheless, evaluating the impact of monitoring would entail weighing its benefits against costs in terms of additional taxation the government must impose to finance it.

\section{The Case of a Uniform Tariff}

Consider now the case of a uniform tariff set, for instance, at $t^{u}=t_{1}^{o}$. As illustrated in figure 2, with this tariff structure firm 1 imports $x_{1}^{u}=x_{1}^{o}$, while firm 2 imports $x_{2}^{u}>x_{2}^{o}$. 

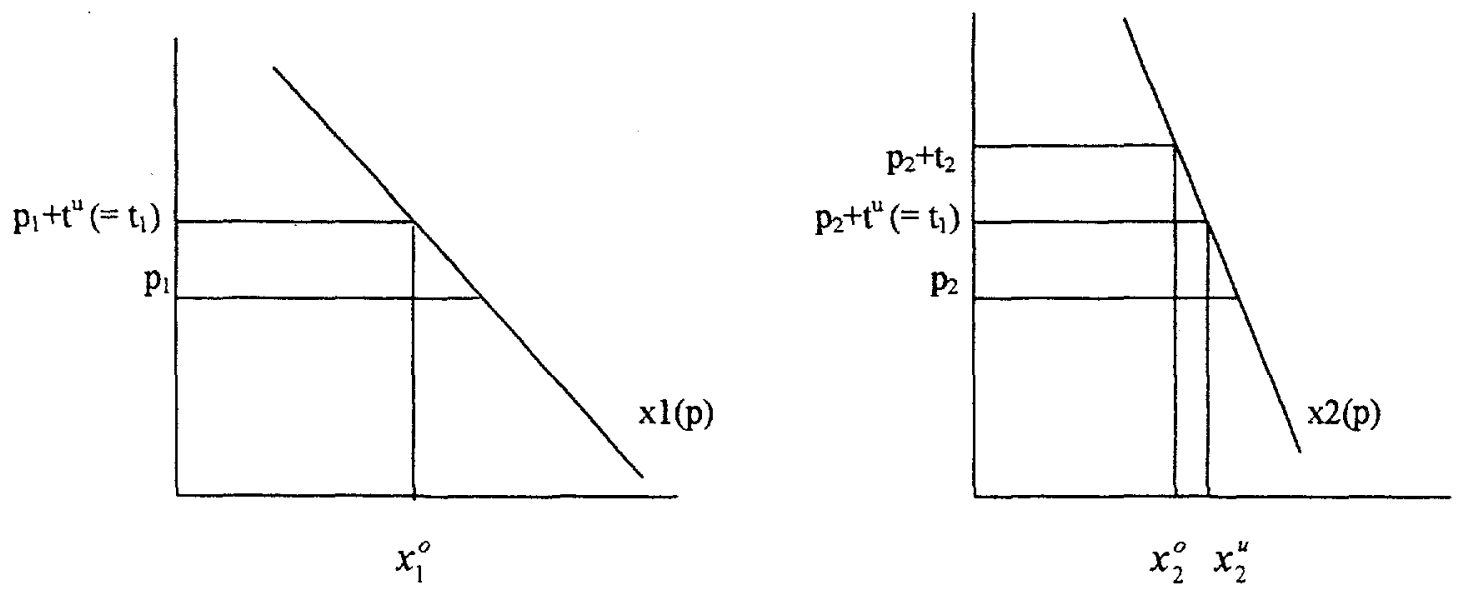

Figure 2: The uniform tariff

When compared with Ramsey's benchmark, the uniform tariff induces two effects. First, the lower tariff on good 2 increases its demand, thereby generating an efficiency gain and an improvement in revenues due to the increase in the tax base. Second, government revenues decrease because good 2 is subject to a lower tax rate. When these two effects are weighed against each other, the Ramsey tariff without corruption not surprisingly dominates the uniform tariff - after all, Ramsey's is the optimal tariff.

However, when compared with Ramsey taxation with corrupt custom officials (the "threat" and "lure" cases combined), the uniform tariff delivers both higher revenues and a welfare improvement. With a uniform tariff, customs officials have no opportunity to misclassify goods and thereby no possibility to divert revenues from the government. Moreover, both goods are subject to lower effective tariff rates, which implies increased demand for the goods, and an improvement in both efficiency and government revenues.

Table 1 summarizes the "threat" and the "lure" effects and reports payoffs for government, officials, and importers under Ramsey tariffs - with and without corruption - and under the uniform tariff rate.

\section{The Empirical Test}

The argument developed above suggests that countries with highly differentiated trade tariffs across goods should ceteris paribus be more vulnerable to corruption. 
It is interesting to see whether this conjecture stands empirical investigation. Relating some measure of corruption in the customs with the standard deviation of trade tariffs across countries provides a natural and simple way test for the claim.

The Global Competitiveness Survey 1998 reports a measure of corruption where customs related bribery is explicitly accounted for. A low value of the index (GCS), which ranges from 1 to 7 , indicates "irregular, additional payments connected with import and export permits, business licenses, exchange controls, tax assessments, police protection or loan applications". This index is be particularly informative for our purposes since is constructed on the basis of a survey of local entrepreneurs who are the likely players in the interactions we described.

The index covers 72 countries and is available for 1997 or 1998 .

Standard deviations of trade tariffs (SDV) are available from World Development Indicators and UNCTAD for a total of 58 countries. Data are for 1998 or for the closest year available.

GCS and SDV are jointly available for only 35 countries, mostly of the developing world. Figure 3 shows their plot.

A simple regression of GCS on SDV, highlights the expected negative correlation between the two indexes: the coefficient reported in column 1 of table 2 indicates that higher standard deviations of trade tariffs are significantly associated with higher measured corruption (lower values of GCS).

To correct for possible omitted variable bias on the estimated coefficient of SDV, we include in the regression the natural logarithm of income (L_INCOME), to account for the fact that corruption might simply be a function of the level of development of a country; and dummies indicating the legal origin of countries, to capture the effect of structural differences in legal systems.

Finally, SDV might proxy not only for the diversification of tariffs across goods, but also for the degree of uncertainty surrounding the imposition of trade taxes. To avoid misinterpretations of the estimated coefficient on SDV, we include a proxy for the degree of uncertainty in the level of import taxes (UNCERTAINTY). ${ }^{6}$

\footnotetext{
${ }^{6}$ UNCERTAINTY is constructed to measure the likelihood of future changes in the average rate of import taxes during a 12 month period. UNCERTAINTY ranges from 0 to 100 and is available for 102 countries. See Kaufmann et al. 1999.
} 
When the controls are added, the negative relationship between GCS and SDV persists, though slightly weakened.

A concern in the interpretation of the OLS coefficient on SDV regards the possibility that a highly differentiated trade tariff menu may be endogenous to corruption. It is indeed conceivable that in a highly corrupted regime, powerful customs administrators might lobby for a tariff structure that maximizes their bribe collection. If this were the case, the correlation between GCS and SDV would then reflect a causality running from corruption to standard deviation and not vice versa, as we argue here.

To correct for this possible source of bias, we re-estimate the relationship while instrumenting for the standard deviation of tariffs. Term of trade shocks (TTS) are a promising instrument. Policymakers are likely to change the tariff structure in response to terms of trade shocks, thereby inducing a correlation between TTS and the standard deviation of tariff rates. Moreover, changes in terms of trade are thought of as exogenous shocks to the economy and therefore are likely to be uncorrelated with the error in our main regression. To be able to assess the lack of correlation between the errors in the regression of interest and the instruments through the test of over-identifying restrictions, an additional instrument is included: the average Gini coefficient at the beginning of the decade (from Deininger and Squire 1996). The two instruments are overall good predictors of the standard deviation of tariff rates, as highlighted by the reported P-value associated with the F-test of joint significance of the instruments in the first stage regression. Moreover, the over-identifying restriction test indicates that the instruments are valid.

The results of the IV estimation are reported in table 2, column 3 . The association between corruption and standard deviation of tariffs is robust to instrumenting and significant.

Although we cannot rule out that the GCS index is only an imperfect measure of corruption in customs administration and that the results of the estimation might be driven by the limited number of countries for which the data are available, the evidence presented here suggests an important association between diversification of trade tariff menus and levels of corruption. 


\section{Conclusions}

By explicitly accounting for the interaction between importers and corrupt customs officials, we have shown that opting for a uniform tariff on import goods can deliver higher revenues and welfare than optimally-set (Ramsey) tariffs when corruption is pervasive. This happens because uniform protection on imports restricts the ability of customs officials to exploit the wedge between tariff rates on different goods and thereby appropriate government revenues and impose efficiency losses on the economy.

An empirical test shows a robust association between standard deviation of trade tariffs and measured corruption across countries, suggesting that a highly diversified trade tariff menu might actually fuel bribe taking behavior.

The message of this paper - that the government faces a trade-off between optimallyset, differentiated tax rates and the distortions that public officials can introduce by exploiting these differences in the tax rates - can be readily generalized to other tax and tariff setting situations. 


\section{References}

Deininger, Klaus and Lyn Squire (1996). "A New Dataset Measuring Income Inequality," World Bank Economic Review, September, vol. 10, pp.565-91.

Kaufmann, Daniel, Aart Kraay, and Pablo Zoido-Lobaton (1999). "Governance Matters," Manuscript, The World Bank.

La Porta, Rafael, Florencio Lopez de Silanes, Andrei Shleifer, and Robert Vishny (1999). "The Quality of Government," Journal of Law, Economics, and Organization, vol. 15, pp. $222-279$.

Pangariya, Arvind and Dani Rodrik (1993). "Political-Economy Arguments for Uniform Tariff," International Economic Review, vol.76, pp.685-703.

Thomas, Vinod, John Nash et al. (1991). Best Practices in Trade Policy Reform, World Bank Publication, Oxford University Press.

Varian, Hal (1992). Microeconomic Analysis, W.W. Norton \& co., New York.

The World Bank (1998). Global Competitiveness Survey. -(1999). World Development Indicators. 
Figure 3. Correlation between absence of corruption (GCS index) and standard deviation of trade tariffs

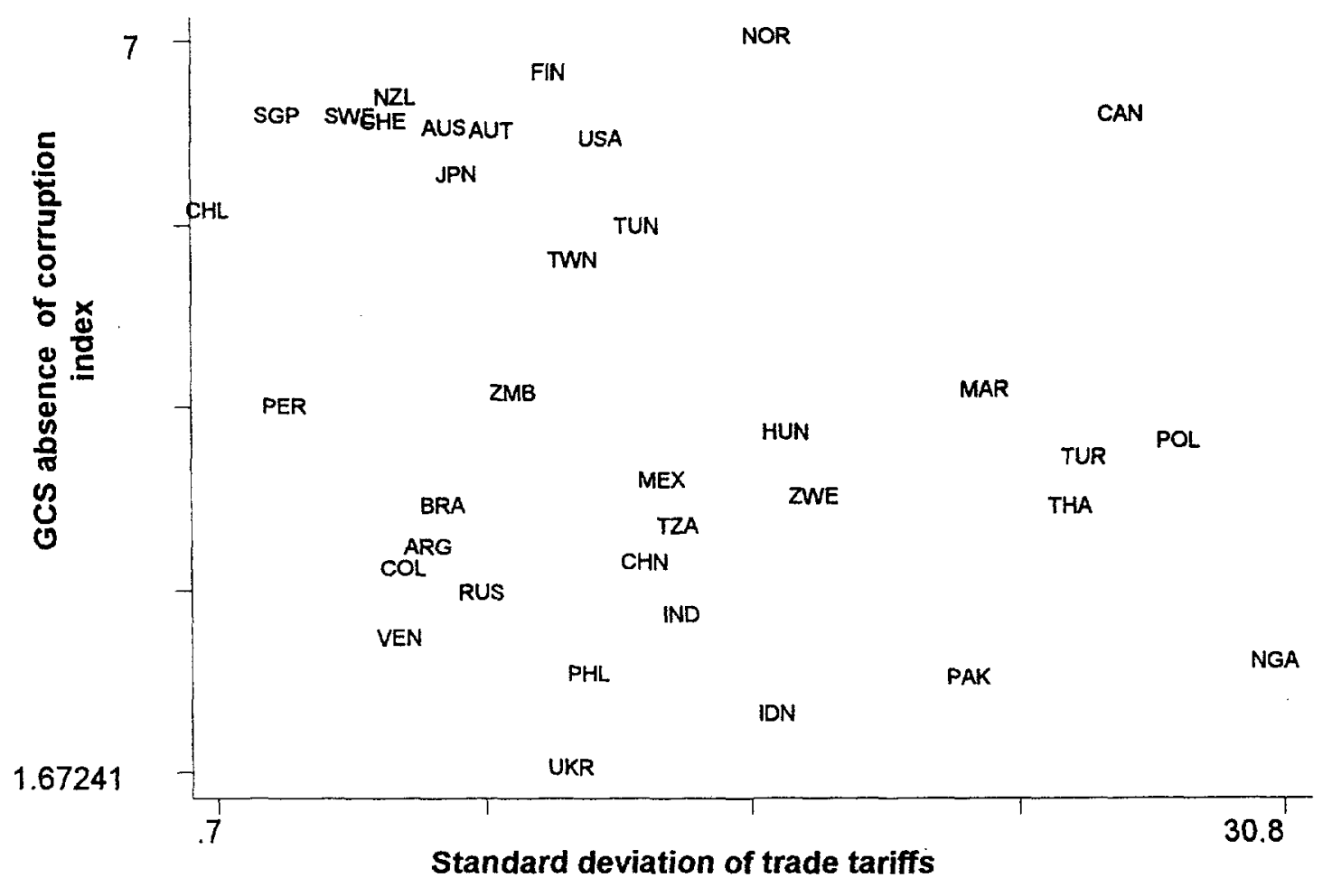


Table 1. Government, firms, and custom officials payoffs under different regimes

\begin{tabular}{|c|c|c|c|c|c|}
\hline & \multicolumn{4}{|c|}{ Ramsey (optimal) tariff rates } & \multirow[t]{3}{*}{ Uniform tariff } \\
\hline & \multirow{2}{*}{$\begin{array}{c}\text { Honest custom } \\
\text { officials }\end{array}$} & \multicolumn{3}{|c|}{ Corrupt custom officials } & \\
\hline & & Threat & Lure & Threat and Lure & \\
\hline $\begin{array}{l}\text { Government } \\
\text { Revenues }\end{array}$ & $t_{1}^{o} x_{1}^{o}+t_{2}^{o} x_{2}^{o}$ & $t_{1}^{o} \hat{x}_{1}+t_{2}^{o} x_{2}^{o}$ & $t_{1}^{o} x_{1}^{o}+t_{1}^{o} x_{2}^{o}$ & $t_{1}^{o} \hat{x}_{1}+t_{1}^{o} x_{2}^{o}$ & $t_{1}^{u} x_{1}^{o}+t_{1}^{u} x_{2}^{u}$ \\
\hline Firm 1 & $-t_{1}^{o} x_{1}^{o}$ & $-t_{2}^{o} \hat{x}_{1}$ & $-t_{1}^{o} x_{1}^{o}$ & $-t_{2}^{o} \hat{x}_{1}$ & $-t_{1}^{u} x_{1}^{o}$ \\
\hline Firm 2 & $-t_{2}^{0} x_{2}^{o}$ & $-t_{2}^{o} x_{2}^{o}$ & $-t_{2}^{o} x_{2}^{o}$ & $-t_{2}^{o} x_{2}^{o}$ & $-t_{1}^{u} x_{2}^{u}$ \\
\hline Custom officials & 0 & $\left(t_{2}^{o}-t_{1}^{o}\right) \hat{x}_{1}$ & $\left(t_{2}^{o}-t_{1}^{o}\right) x_{2}^{o}$ & $\left(t_{2}^{o}-t_{1}^{o}\right)\left(\hat{x}_{1}+x_{2}^{o}\right)$ & 0 \\
\hline $\begin{array}{l}\text { Welfare change } \\
\text { with respect to } \\
\text { benchmark }\end{array}$ & (benchmark) & $-1 / 2\left(t_{2}^{o}-t_{1}^{o}\right)\left(x_{1}^{o}-\hat{x}_{1}\right)$ & 0 & $-1 / 2\left(t_{2}^{o}-t_{1}^{o}\right)\left(x_{1}^{o}-\hat{x}_{1}\right)$ & $+1 / 2\left(t_{2}^{o}-t_{1}^{o}\right)\left(x_{2}^{u}-x_{2}^{o}\right)$ \\
\hline
\end{tabular}

Notation is in reference to figure 1. In the case of Ramsey taxation with corrupt customs officials, payoffs are calculated under the assumption that customs officials are able to capture the entire rent in the bargaining process with importers. 
Table 2. Absence of corruption and standard deviation of trade tariffs

\begin{tabular}{|c|c|c|c|}
\hline & Simple OLS & OLS with controls & 2 SLS \\
\hline Standard deviation of trade tariffs & $\begin{array}{l}-0.05 \\
(2.01)\end{array}$ & $\begin{array}{c}-0.03 \\
(-1.412)\end{array}$ & $\begin{array}{c}-0.13 \\
(-2.26)\end{array}$ \\
\hline DRI & & $\begin{array}{c}0.02 \\
(1.54)\end{array}$ & $\begin{array}{c}0.02 \\
(1.55)\end{array}$ \\
\hline Log of income & & $\begin{array}{c}0.65 \\
(2.733)\end{array}$ & $\begin{array}{c}0.66 \\
(1.73)\end{array}$ \\
\hline Legal origin: British & & $\begin{array}{c}-0.01 \\
(-0.046)\end{array}$ & $\begin{array}{c}0.76 \\
(1.26)\end{array}$ \\
\hline Legal origin: French & & $\begin{array}{c}-0.92 \\
(-2.00)\end{array}$ & $\begin{array}{l}-0.53 \\
(-0.73)\end{array}$ \\
\hline Legal origin: Socialist & & $\begin{array}{l}-1.07 \\
(-2.78)\end{array}$ & $\begin{array}{l}-0.36 \\
(-0.57)\end{array}$ \\
\hline Legal origin: Scandinavian & & $\begin{array}{l}0.61 \\
(2.2)\end{array}$ & $\begin{array}{c}0.93 \\
(1.43)\end{array}$ \\
\hline $\mathrm{N}$ & 36 & 34 & 24 \\
\hline $\mathrm{R}^{2}$ & 0.08 & 0.74 & 0.63 \\
\hline $\begin{array}{l}\text { Joint significance of instruments in } \\
\text { first stage regression } \\
\text { (P-value for F-test) }\end{array}$ & & & 0.05 \\
\hline $\begin{array}{l}\text { Over-identifying restrictions test } \\
\text { (P value) }\end{array}$ & & & 0.53 \\
\hline
\end{tabular}




\section{Data Description}

GCS

Irregular, additional payments connected with import and export permits, business licenses, exchange controls, tax assessments, police protection or loan applications for the years 1997/1998. Source: Global Competitiveness Survey, The World Bank, 1999.

SDV_TARIFFS Standard deviation of tariff rates. Source: World Development Indicators and UNCTAD for Morocco, Pakistan, Switzerland.

INCOME

Natural logarithm of real income per capita. Source: World Development Indicators, The World Bank.

LEGAL ORIGIN Origin of a country legal system. Source: La Porta et al (1998).

UNCERTAINTY Likelihood of a 10-percentage point increase in the average rate of import taxes/tariffs during any 12 months. Source: Kaufmann et al. (1999); originally from Country Risk Services.

TOT95

Terms of trade shocks for 1995 , calculated as

$$
100 *\left[\left(P X / P X_{t-1}-1\right) * X_{t-1}-\left(P M_{1} / P M_{t-1}-1\right) * M_{t-1}\right] / R G D P_{t-1}, \text { where } \mathrm{X}
$$

M, RGDP are export, imports, and GDP in real terms (1987 prices), and PX, PM are export and import prices, respectively.

GINI Average Gini coefficient for early nineties. Source: Deininger and Squire (1996). 


\section{Data Appendix}

\begin{tabular}{|c|c|c|c|c|c|c|c|c|}
\hline \multirow{2}{*}{$\begin{array}{l}\text { Country } \\
\text { code }\end{array}$} & \multirow[t]{2}{*}{ GCS } & \multirow[t]{2}{*}{ SDV } & \multirow{2}{*}{$\begin{array}{l}\text { Trade policy } \\
\text { Uncertainty }\end{array}$} & \multicolumn{5}{|c|}{ Legal Origin } \\
\hline & & & & $\begin{array}{c}\text { British } \\
0\end{array}$ & $\begin{array}{c}\text { French } \\
1\end{array}$ & $\begin{array}{c}\text { Socialist } \\
0\end{array}$ & $\underset{0}{\text { German }}$ & $\begin{array}{c}\text { Scandinavian } \\
0\end{array}$ \\
\hline AUS & 6.3 & 7.4 & 95 & 1 & 0 & 0 & 0 & 0 \\
\hline AUT & 6.3 & 8.7 & 95 & 0 & 0 & 0 & 1 & 0 \\
\hline BRA & 3.6 & 7.3 & 20 & 0 & 1 & 0 & 0 & 0 \\
\hline CAN & 6.4 & 26.5 & 90 & 1 & 0 & 0 & 0 & 0 \\
\hline CHE & 6.4 & 5.7 & 95 & 0 & 0 & 0 & 1 & 0 \\
\hline $\mathrm{CHL}$ & 5.7 & 0.7 & 92 & 0 & 1 & 0 & 0 & 0 \\
\hline $\mathrm{CHN}$ & 3.2 & 13 & 72 & 0 & 0 & 1 & 0 & 0 \\
\hline COL & 3.1 & 6.2 & 82 & 0 & 1 & 0 & 0 & 0 \\
\hline FIN & 6.7 & 10.3 & 95 & 0 & 0 & 0 & 0 & 1 \\
\hline HUN & 4.1 & 17 & 90 & 0 & 0 & 1 & 0 & 0 \\
\hline IDN & 2.1 & 16.7 & 68 & 0 & 1 & 0 & 0 & 0 \\
\hline IND & 2.8 & 14 & 65 & 1 & 0 & 0 & 0 & 0 \\
\hline JPN & 6.0 & 7.7 & 98 & 0 & 0 & 0 & 1 & 0 \\
\hline MAR & 4.4 & 22.65 & 82 & 0 & 1 & 0 & 0 & 0 \\
\hline MEX & 3.8 & 13.5 & 97 & 0 & 1 & 0 & 0 & 0 \\
\hline NGA & 2.4 & 30.8 & 60 & 1 & 0 & 0 & 0 & 0 \\
\hline NOR & 7.0 & 16.5 & 95 & 0 & 0 & 0 & 0 & 1 \\
\hline$N Z L$ & 6.6 & 6 & 95 & 1 & 0 & 0 & 0 & 0 \\
\hline PAK & 2.3 & 22.13 & 68 & 1 & 0 & 0 & 0 & 0 \\
\hline PER & 4.3 & 2.9 & 56 & 0 & 1 & 0 & 0 & 0 \\
\hline $\mathrm{PHL}$ & 2.4 & 11.4 & 75 & 0 & 1 & 0 & 0 & 0 \\
\hline POL & 4.1 & 28.1 & 88 & 0 & 0 & 1 & 0 & 0 \\
\hline RUS & 3.0 & 8.4 & 70 & 0 & 0 & 1 & 0 & 0 \\
\hline SGP & 6.4 & 2.7 & 92 & 1 & 0 & 0 & 0 & 0 \\
\hline SWE & 6.4 & 4.8 & 95 & 0 & 0 & 0 & 0 & 1 \\
\hline THA & 3.6 & 25 & 80 & 1 & 0 & 0 & 0 & 0 \\
\hline TUN & 5.6 & 12.8 & 92 & 0 & 1 & 0 & 0 & 0 \\
\hline TUR & 3.9 & 25.4 & 80 & 0 & 1 & 0 & 0 & 0 \\
\hline TWN & 5.4 & 11 & 90 & & & & & \\
\hline TZA & 3.4 & 13.9 & 70 & 1 & 0 & 0 & 0 & 0 \\
\hline USA & 6.3 & 11.8 & 90 & 1 & 0 & 0 & 0 & 0 \\
\hline VEN & 2.6 & 6.1 & 70 & 0 & 1 & 0 & 0 & 0 \\
\hline$Z M B$ & 4.4 & 9.3 & 64 & 1 & 0 & 0 & 0 & 0 \\
\hline ZWE & 3.7 & 17.8 & 61 & 1 & 0 & 0 & 0 & 0 \\
\hline
\end{tabular}





\section{Policy Research Working Paper Series}

\begin{tabular}{|c|c|c|c|c|}
\hline & Title & Author & Date & $\begin{array}{l}\text { Contact } \\
\text { for paper }\end{array}$ \\
\hline WPS2201 & $\begin{array}{l}\text { Financial Development and Industrial } \\
\text { Capital Accumulation }\end{array}$ & Biagio Bossone & October 1999 & $\begin{array}{l}\text { E. Mekhova } \\
85984\end{array}$ \\
\hline WPS2202 & $\begin{array}{l}\text { Specialization without Regret: } \\
\text { Transfer Rights, Agricultural } \\
\text { Productivity, and Investment in an } \\
\text { Industrializing Economy }\end{array}$ & $\begin{array}{l}\text { Michael R. Carter } \\
\text { Yang Yao }\end{array}$ & October 1999 & $\begin{array}{l}\text { M. Fernandez } \\
33766\end{array}$ \\
\hline WPS2203 & $\begin{array}{l}\text { Market versus Administrative } \\
\text { Reallocation of Agricultural Land } \\
\text { in a Period of Rapid industrialization }\end{array}$ & $\begin{array}{l}\text { Michael R. Carter } \\
\text { Yang Yao }\end{array}$ & October 1999 & $\begin{array}{l}\text { M. Fernandez } \\
33766\end{array}$ \\
\hline WPS2204 & Corruption under Moral Hazard & $\begin{array}{l}\text { Gunnar S. Eskeland } \\
\text { Henrik Thiele }\end{array}$ & October 1999 & $\begin{array}{l}\text { H. Sladovich } \\
37698\end{array}$ \\
\hline WPS2205 & $\begin{array}{l}\text { Foreign-Owned Capital and } \\
\text { Endogenous Tariffs }\end{array}$ & Marcelo Olarreaga & October 1999 & $\begin{array}{l}\text { L. Tabada } \\
36896\end{array}$ \\
\hline WPS2206 & $\begin{array}{l}\text { Household Childcare Choices and } \\
\text { Women's Work Behavior in Russia }\end{array}$ & Michael M. Lokshin & October 1999 & $\begin{array}{l}\text { P. Sader } \\
33902\end{array}$ \\
\hline WPS2207 & $\begin{array}{l}\text { Jamaica's Food Stamp Program: } \\
\text { Impacts on Poverty and Welfare }\end{array}$ & $\begin{array}{l}\text { Kene Ezemenari } \\
\text { Kalanidhi Subbarao }\end{array}$ & October 1999 & $\begin{array}{l}\text { G. Peralta } \\
37405\end{array}$ \\
\hline WPS2208 & $\begin{array}{l}\text { Ethnic Partition as a Solution to } \\
\text { Ethnic War: An Empirical Critique } \\
\text { of the Theoretical Literature }\end{array}$ & Nicholas Sambanis & October 1999 & $\begin{array}{l}\text { H. Sladovich } \\
37698\end{array}$ \\
\hline WPS2209 & $\begin{array}{l}\text { Does Corruption Relieve Foreign } \\
\text { Investors of the Burden of Taxes } \\
\text { and Capital Controls? }\end{array}$ & Shang-Jin Wei & October 1999 & $\begin{array}{l}\text { H. Sladovich } \\
37698\end{array}$ \\
\hline WPS2210 & $\begin{array}{l}\text { The Sliperry Slope: Explaining the } \\
\text { Increase in Extreme Poverty in Urban } \\
\text { Brazil, 1976-96 }\end{array}$ & $\begin{array}{l}\text { Francisco H. G. Ferreira } \\
\text { Ricardo Paes de Barros }\end{array}$ & October 1999 & $\begin{array}{l}\text { G. llogon } \\
33732\end{array}$ \\
\hline WPS2211 & $\begin{array}{l}\text { Competition Policy, Developing } \\
\text { Countries, and the World Trade } \\
\text { Organization }\end{array}$ & $\begin{array}{l}\text { Bernard Hoekman } \\
\text { Peter Hoimes }\end{array}$ & October 1999 & $\begin{array}{l}\text { L. Tabada } \\
36896\end{array}$ \\
\hline WPS2212 & $\begin{array}{l}\text { Is African Manufacturing Skill- } \\
\text { Constrained? }\end{array}$ & $\begin{array}{l}\text { Howard Pack } \\
\text { Christina Paxson }\end{array}$ & October 1999 & $\begin{array}{l}\text { H. Sladovich } \\
37698\end{array}$ \\
\hline WPS2213 & $\begin{array}{l}\text { Fiscal Solvency and Sustainability } \\
\text { in Economic Management }\end{array}$ & Hinh T. Dinh & October 1999 & $\begin{array}{l}\text { M. Rani } \\
32057\end{array}$ \\
\hline
\end{tabular}


Policy Research Working Paper Series

Title

WPS2214 Trade Policy and Market Access Issues for Developing Countries: Implications for the Millennium Round

WPS2215 Implementation of Uruguay Round Commitments: The Development Challenge
Author

Constantine Michalopoulos October 1999

J. Michael Finger

Philip Schuler
Date

Contact for paper

L. Tabada 36896

October 1999

L. Tabada 36896 